\title{
Repeated Creep Events on the San Andreas Fault Near Parkfield, California, Recorded by a Strainmeter Array
}

\author{
NeIL R. GoultY ${ }^{1}$ \\ Department of Geophysics and Planetary Physics, School of Physics \\ The University, Newcastle upon Tyne, NEI 7RU, England \\ RaLPH Gilman \\ Seismological Laboratory. California Institute of Technology \\ Pasadena, California 9/125
}

\begin{abstract}
Following the 1966 Parkfield-Cholame (California) earthquakes a creepmeter was installed across the fresh surface break of the San Andreas fault at Carr Ranch (now part of the Jack Ranch), $10 \mathrm{~km}$ southeast of Parkfield. It has recorded continuing slip which since the end of 1968 has occurred at about $10 \mathrm{~mm} \mathrm{yr} \mathrm{r}^{-1}$, occurring primarily in discrete events at intervals of a few months. In April 1976 an array of four strainmeters was installed near this creepmeter at distances between 0.2 and $2.2 \mathrm{~km}$ from the fault to detect the elastic strain fields associated with creep events on the fault. Four similar sets of signals have since been observed on the strainmeter array, separated by intervals of 4 to 5 months. A week after three of these events, creep began at the Carr Ranch creepmeter, but no signals were detected by the strainmeters while the creepmeter was recording slip. Analysis of the strainmeter signals shows that they can be modeled by a slip zone on the fault $640 \mathrm{~m}$ long and extending from 30 to $510 \mathrm{~m}$ in depth, with right lateral slip of about $3.5 \mathrm{~mm}$. Propagation of a dislocation from the lower northwest corner of the slip zone to the upper southeast corner is indicated. The phenomenon may be due to an asperity or an area of higher friction on the fault at Carr Ranch, which is repeatedly loaded to failure by steady slip on the fault around it. This is the first report of a well-defined fault creep event which repeats itself with a high degree of similarity and which has been observed at a distance of over $2 \mathrm{~km}$ from the fault.
\end{abstract}

\section{INTRODUCTION}

Creep events with amplitudes of several millimeters have been reported at many creepmeter sites along the San Andreas fault. At other locations, continuous slip has been recorded with no discrete events [Yamashita and Burford, 1973; Nason et al., 1974]. These observations have been made with recording creepmeters spanning the active trace of the fault. A single creepmeter will only give the time history of slip on the fault at that location. An array of creepmeters along the fault can put bounds on the horizontal extent of a creep event but cannot give any information on its vertical extent or propagation velocity.

Frank [1973] discussed the possibility of detecting the elastic strain fields associated with creep events on a fault by deploying arrays of strainmeters and tiltmeters near the fault. Provided that a sufficiently large number of instruments record signals caused by the creep event, one should be able to deduce a plausible dislocation model which would reproduce the observed signals. In theory, there will never be a unique solution unless various restricting assumptions are made. Any set of signals may be fitted by a hodgepodge of dislocations on the fault plane, and even on hypothetical subsidiary fault planes, or by postulating inhomogeneities in the elastic behavior of the ground. With smaller amounts of data or an unfavorable distribution of instruments, there will be a large number of plausible models to consider, in which case it would be misleading to favor a single model without additional constraints.

McHugh and Johnston [1976] reported a search for tiltmeter signals at the times that creep events were recorded on nearby creepmeters across the San Andreas fault in Bear Valley, south

\footnotetext{
${ }^{1}$ Now at National Coal Board, Hobart House, Grosvenor Place, London, SW1X 7AE, England.

Copyright $\odot 1978$ by the American Geophysical Union.
}

Paper number 8 B0599.

0148-0227/78/118B-0599\$01.00 of Hollister, California. Only at one of four biaxial tiltmeter installations were creep-related tilt changes observed, and this tiltmeter was $370 \mathrm{~m}$ from the fault. Dislocation models which reproduced the observed tiltmeter wave forms and creepmeter data also predicted an observable tilt change at another tiltmeter, $1.6 \mathrm{~km}$ from the fault, where no tilt change was observed. McHugh and Johnston were forced to suggest that if their model was realistic, there might be some change in material properties between the fault and the second tiltmeter. Signals were also recorded at the other two tiltmeters with the general characteristics expected of creep events: durations of minutes to hours, in the range of relaxation time constants observed for creep events on creepmeters, and residual tilt offsets. But these were not associated with creep events recorded on the creepmeters. Again, plausible models of dislocations on the fault, which have a good fit to the observed wave forms on each tiltmeter, predicted tilt changes on the other tiltmeter which were not observed. It was suggested that these events might be due to local strain release near each instrument.

A little further northwest along the San Andreas fault, Mortensen et al. [1977] observed changes in water level in the fault zone and anomalous strain and tilt signals $330 \mathrm{~m}$ from the fault while creep events were being recorded on the fault by creepmeters. Models of dislocations penetrating to 0.4- and 2.0-km depth gave a good fit to their data. But further northwest still, near San Juan Bautista, and in Bear Valley, Johnston et al. [1977] were unable to detect significant strain signals $\left(>10^{-8}\right)$ on strainmeters between 1 and $2 \mathrm{~km}$ from the San Andreas fault while creep events were being recorded on the fault. This observation also implies that creep events are relatively shallow.

Here we report observations of repeated fault creep events recorded by an arrăy of four strainmeters at distances between 0.2 and $2.2 \mathrm{~km}$ from the San Andreas fault in Cholame Valley, 
south of Parkfield, California. Episodic creep events recorded on the nearby Carr Ranch creepmeter appear to be intimately related to the events seen by the strainmeters, although signals have not been observed simultaneously on the creepmeter and strainmeters. A model was determined for a propagating dislocation on the fault which reproduces the observed strainmeter wave forms well without the need to assume any variations in the elastic behavior of the ground.

The section of the San Andreas fault in Cholame Valley, between Parkfield and Cholame, is of particular interest, because to the south of Cholame the fault is locked with no creep detected at the surface, while to the north of Parkfield, creep along the surface trace of the fault has been recorded at rates of up to $3 \mathrm{~cm} \mathrm{yr}^{-1}$ [Savage and Burford, 1973]. Four moderate earthquake sequences have broken the San Andreas fault in Cholame Valley in this century, in 1901, 1922, 1934, and 1966 [Brown and Vedder, 1967]. Using seismic and geodetic data collected after the 1966 Parkfield-Cholame earthquakes and with evidence from laboratory experiments, Scholz et al. [1969] deduced the mechanism of slip for the San Andreas fault in this region. They concluded that stick slip accompanied by earthquakes should occur between about 4- and 12$\mathrm{km}$ depth. Below $12 \mathrm{~km}$, stable sliding or plastic friction may be expected because of serpentine alteration of basic rock. Laboratory experiments of Byerlee and Brace [1968] showed that stick slip does not occur for some rock types unless the confining pressure is $\gtrsim 1$ kbar. Accordingly, Scholz et al. expect that aseismic slip can occur above $4 \mathrm{~km}$ without a lithological boundary at that depth. However, they were not able to explain the episodic nature of aseismic slip observed on the Carr $\mathrm{R}$ anch creepmeter, which is the subject of this paper.

\section{INSTRUMENTATION}

The creepmeters and strainmeters used in this project operate on the same principle. The fundamental difference between them is only one of sensitivity and hence of application. Both instruments use an invar wire, held in tension, hanging freely inside a horizontal, buried pipe. In the case of the creepmeter a

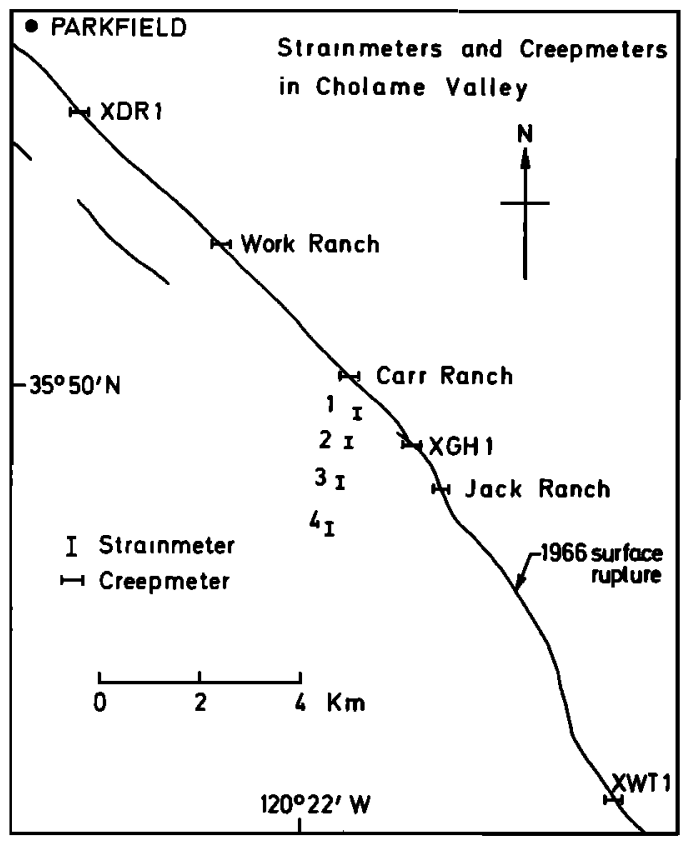

Fig. 1. Locations of strainmeters and creepmeters between Parkfield and Cholame.
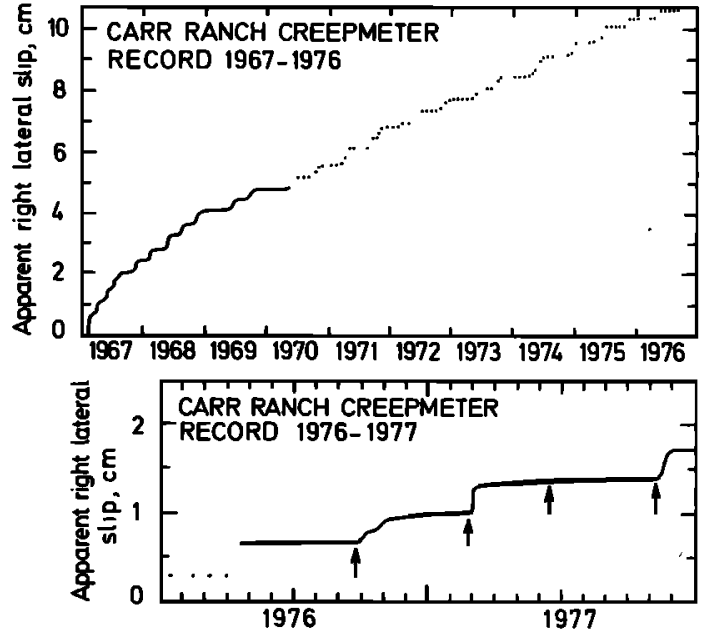

Fig. 2. Record from the Carr Ranch creepmeter. Arrows indicate the times of strainmeter events.

linear potentiometer is used as the transducer. One revolution of the potentiometer spindle is equivalent to about $5 \mathrm{~mm}$ of relative displacement of the.creepmeter mounts, and this is adjusted to be full scale on a Rustrak strip chart recorder which runs at $\frac{1}{2}$ in. $\mathrm{h}^{-1}\left(1.3 \mathrm{~cm} \mathrm{~h}^{-1}\right)$. When the potentiometer is made to exceed one revolution, the chart recorder pen automatically resets to the other side of the chart. About $30 \mathrm{~mm}$ of relative displacement between the mounts can be accommodated before the invar wire has to be reset in the clamp. A dial gauge is also fixed to the instrument so that manual readings may be taken.

The invar wire strainmeters were manufactured at Cambridge University, England, and have been described by King and Bilham [1976]. The transducer employed is a linear variable differential transformer. The signals from all four strainmeters are recorded on the same Rustrak strip chart recorder running at $\frac{1}{2}$ in. $h^{-1}\left(1.3 \mathrm{~cm} \mathrm{~h}^{-1}\right)$, through a stepper switch. The device selects the strainmeter channels in such a way that each records with a different code on the chart paper. Hour marks are provided by an Accutron clock. The strainmeters are each $18 \mathrm{~m}$ long and buried in trenches $1 \mathrm{~m}$ deep. They are hard wired to a central recording pit. Full scale sensitivity on the chart recorder is set at $3 \times 10^{-7}$ strain. Automatic rezeroing is provided first by an electronic chart stepper and second, when the chart stepper range is exceeded, by a small motor driving a weight along the tensioning mass to change the tension in the wire. This arrangement gives an automatic working range of about $10^{-4}$ strain.

\section{OBSERVATIONS}

The Carr Ranch creepmeter was installed in February 1967 (Figure 1), although an earlier instrument ran at the same

TABLE 1. Locations of the Strainmeters

\begin{tabular}{ccc}
\hline & $\begin{array}{c}\text { Distance of Strainmeter } \\
\text { From the Fault, } \\
\mathrm{m}\end{array}$ & $\begin{array}{c}\text { Distance of Strainmeter } \\
\text { Along the Fault From } \\
\text { the Carr Ranch Creepmeter, } \\
\text { m }\end{array}$ \\
\hline 1 & 210 & 550 \\
2 & 715 & 865 \\
3 & 1335 & 1275 \\
4 & 2200 & 1840 \\
\hline
\end{tabular}


TABLE 2. Results From the Creepmeters in Cholame Valley

\begin{tabular}{|c|c|c|c|c|}
\hline Creepmeter & $\begin{array}{l}\text { Latitude, } \\
\text { North }\end{array}$ & $\begin{array}{l}\text { Longitude, } \\
\text { West }\end{array}$ & $\begin{array}{l}\text { Installation } \\
\text { Date }\end{array}$ & Observations of Right Lateral Slip \\
\hline XDR 1 & $35^{\circ} 53.0^{\prime}$ & $120^{\circ} 25.2^{\prime}$ & July 15, 1969 & $\begin{array}{l}\text { about } 1.5 \mathrm{~cm} \mathrm{yr}^{-1} \text {, mainly as } \\
\text { steady creep with occasional } \\
\text { events }\end{array}$ \\
\hline Work Ranch & $35^{\circ} 51.5^{\prime}$ & $120^{\circ} 23.5^{\prime}$ & Sept. 24, 1976 & $\begin{array}{l}8 \mathrm{~mm} \text { of steady creep in the first } \\
\text { year of operation }\end{array}$ \\
\hline Carr Ranch & $35^{\circ} 50.1^{\prime}$ & $120^{\circ} 21.85^{\prime}$ & Feb. 8, 1967 & $\begin{array}{l}\text { about } 1 \mathrm{~cm} \mathrm{yr^{-1 }} \text { in recent years, } \\
\text { mainly as two events per year } \\
\text { with some steady creep }\end{array}$ \\
\hline $\mathrm{XGHI}$ & $35^{\circ} 49.2^{\prime}$ & $120^{\circ} 20.9^{\prime}$ & July 15, 1969 & $\begin{array}{l}\text { about } 2 \mathrm{~mm} \mathrm{yr}^{-1} \text { as occasional } \\
\text { small events with a little steady } \\
\text { creep }\end{array}$ \\
\hline Jack Ranch & $35^{\circ} 48.9^{\prime}$ & $120^{\circ} 20.75^{\prime}$ & Sept. 25, 1976 & $\begin{array}{l}3 \mathrm{~mm} \text { of steady creep in the first } \\
\text { year of operation }\end{array}$ \\
\hline XWT1 & $35^{\circ} 45.4^{\prime}$ & $120^{\circ} 18.5^{\prime}$ & June 5, 1969 & $\begin{array}{l}\text { two large events of } 9 \mathrm{~mm} \text { each in } \\
\text { the first years of operation, with } \\
\text { negligible steady creep }\end{array}$ \\
\hline
\end{tabular}

place from July to September 1966, having been installed very soon after the earthquakes of June 27, 1966 [Smith and Wyss, 1968]. The record from the Carr Ranch creepmeter is shown in Figure 2. Readings of the dial gauge were taken daily until 1969 and then monthly until April 1976, since when the signal has been recorded continuously. The array of four strainmeters (Figure 1) was installed in April 1976. Each is orientated north-south at approximately $45^{\circ}$ to the strike of the fault. Strainmeters parallel or perpendicular to the fault would be insensitive to very long rising screw dislocations on the fault [Frank, 1973]. In practice, no such dislocations have been observed, and any orientation might have done as well as the chosen one. The relative positions of the strainmeters, which are all on a line trending $N 15^{\circ} \mathrm{E}$, to each other and to the fault (Table 1) were chosen both for practical siting considerations and to get maximum information on the vertical and horizontal extent of creep events using a small number of instruments.

Five other creepmeters are shown in Figure I. XDR1, XGH1, and XWT1 are U.S. Geological Survey creepmeters installed in 1969 [Yamashita and Burford, 1973]. A brief description of the data recorded by each creepmeter is given in Table 2. In general, a decline in creep rate is observed toward the southeast end of Cholame Valley. Creep is episodic at Carr Ranch, XGH 1, and XWTI but takes place more steadily at the other creepmeters.

The first signals of interest recorded by the strainmeter array occurred on September 24, 1976. A span of several days of data around this event is shown in Figure 3. The contribution of the earth tides may be seen in the signals from each strainmeter. Diurnal signals are also recorded with different amplitudes on each strainmeter. The strainmeters are all installed on the valley floor, where the topography is nearly flat, so these diurnal signals are attributed to thermoelastic strains caused by insolation combined with local inhomogeneities in the ground near each instrument, but they could also be due to a direct temperature effect on the instruments. When the diurnal contamination is small, inspection of the records shows that the earth tides signals are very similar on all the strainmeters. Small-scale irregularities in the ground near each strainmeter should not cause much distortion in tidal or creep event signals, as the surficial material will be constrained to move with the material below. The event of September 24, 1976, is shown in more detail in Figure 4. No signal was recorded by the Carr Ranch creepmeter at that time. However,

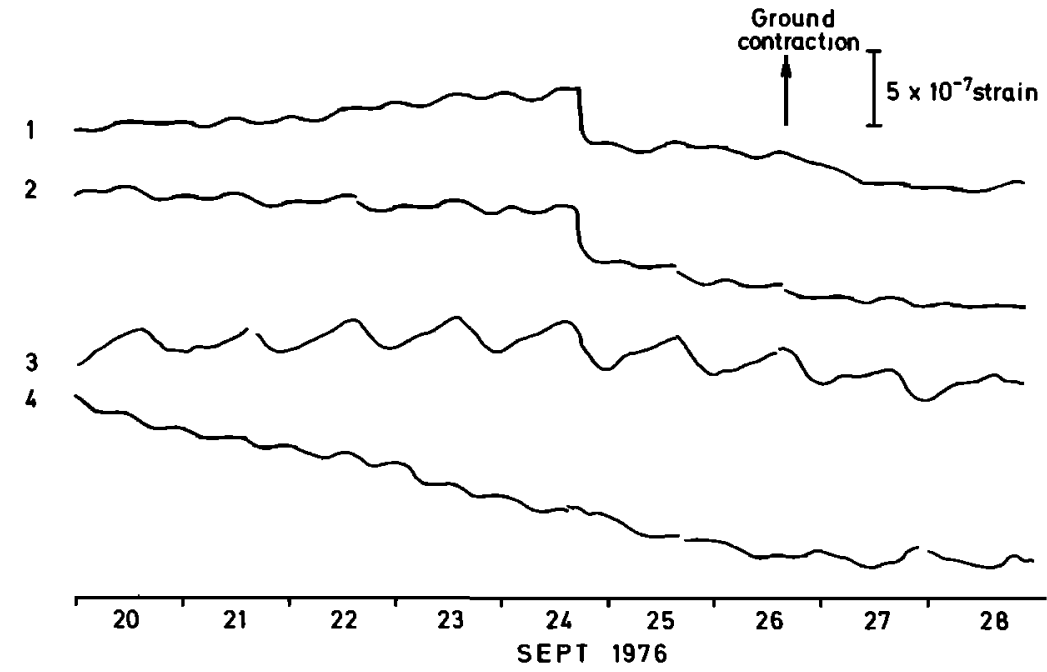

Fig. 3. A few days of record from the four strainmeters around the time of the event of September 24, 1976. This record was copied directly from the strip chart, except for the removal of steps introduced by the automatic bias stepper to stop the trace from going off-scale. In particular, two 'glitches' on the record of strainmeter 4 occurred very shortly belore this creep event. They are thought to be of instrumental origin and are not uncommon. Gaps are also due to instrumental noise. 


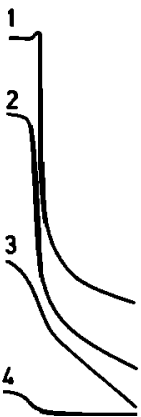

24 Sept 1976

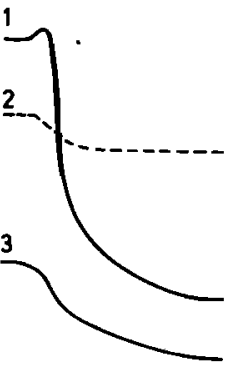

22 Feb 1977

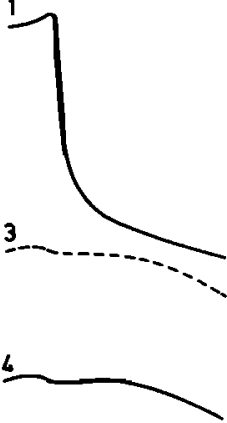

16 June 1977

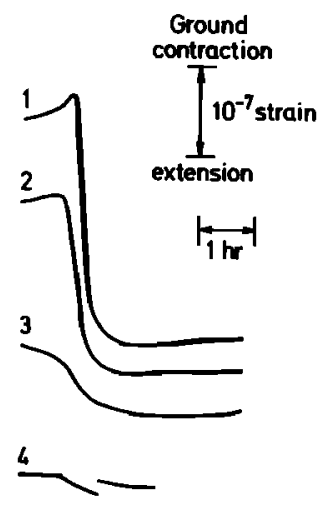

g Nov 1977

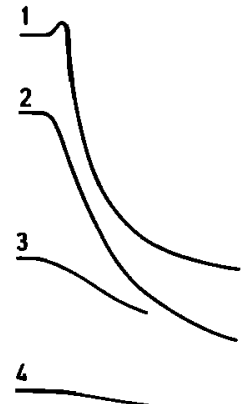

$$
\begin{aligned}
& \text { Theoretical } \\
& D_{0}=3.5 \mathrm{~mm} \\
& r=2500 \mathrm{sec} \\
& r=1 \mathrm{~km} / \mathrm{hr}^{-1}
\end{aligned}
$$

Fig. 4. Four similar events observed by the strainmeters and theoretical wave forms obtained from the dislocation model of Figure 5. Dashed traces indicale that the appropriate strainmeters were operating at unknown reduced gains due to electrical faults. These records were traced directly from the strip charts and include a 'glitch' in the record from strainmeter 4 on November 9, 1977

the creepmeter did record a total of $2.7 \mathrm{~mm}$ of slip during October, mainly in two episodes of 1 week each (Figure 2). On February 22, 1977, another event was recorded by the strainmeter array with signals very similar to those of the previous event (Figure 4). The primary difference on this occasion was that the duration of the signals was doubled. Again, the Carr Ranch creepmeter recorded no slip until 1 week later. Then $3.1 \mathrm{~mm}$ of slip accumulated between March 2 and 5 . No anomalous signals in the strainmeter records could be detected while this comparatively rapid creep event was in progress. It suggests that the creep events recorded by the Carr Ranch creepmeter are very small in extent. A third event, with similar wave forms, was recorded by the strainmeters on June 16, 1977 , and a fourth on November 9, 1977. Negligible creep was recorded by the Carr $\mathrm{R}$ anch creepmeter after the third event, but between November 17 and 28 it recorded $3 \mathrm{~mm}$ of slip.

\section{Dislocation Model}

The equations of Press [1965] for a vertical rectangular slip zone buried in a homogeneous half space were used to compute the strains expected at each strainmeter. Initially, a fit was found to the total offsets recorded by each strainmeter, regardless of the shapes of the waveforms. Only at one region on the fault could we find a slip zone having pure right lateral strike slip which gave approximately equal offsets on strainmeters 1 and 2, as observed (Figure 4). It was then assumed that the amount of slip was $3.5 \mathrm{~mm}$, a little larger than the size of the

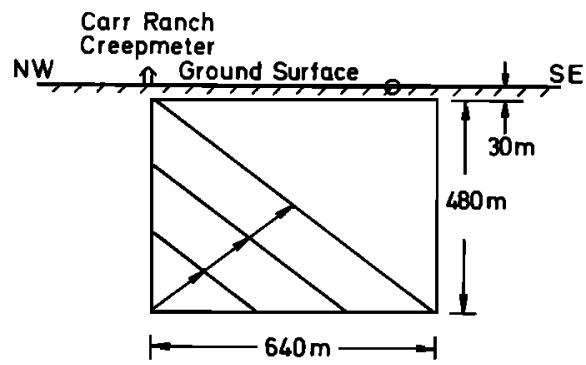

Fig. 5. Dislocation model to give theoretical wave forms of Figure 4 , assuming pure right lateral strike slip of $3.5 \mathrm{~mm}$ with $1-e^{-t / \tau}$ dependence. A small circle is marked where the perpendicualr projection of strainmeter 1 intersects the fault. The arrows indicate the direction of propagation of the dislocation front. surface creep events following the strainmeter events (Figure 2). This defined the rectangular slip zone on the fault (Figure 5). It is $640 \mathrm{~m}$ long and extends from 30 to $510 \mathrm{~m}$ in depth. It seemed reasonable to take a slightly larger amount of slip than that observed on the creepmeter during the subsequent events, because the creepmeter does record some smooth continuous creep between events.

To match the observed wave forms, it was assumed that each point within the slip zone would undergo relaxing slip in accordance with the equation

$$
D(t)=D_{0}\left(1-e^{-t / \tau}\right)
$$

where $D(t)$ is displacement at time $t, D_{0}$ is the final value of displacement, $t$ is time, and $\tau$ is a constant known as the relaxation time. The dislocation front was propagated from the lower northwest corner of the slip zone to the upper southeast corner, as is shown in Figure 5. Propagation velocity and relaxation time were varied until a good fit to the observed signals was obtained. The theoretical wave forms of Figure 4, which match the second and third events well, were obtained with a relaxation time of $2500 \mathrm{~s}$ and a propagation velocity of 1 $\mathrm{km} \mathrm{hr} \mathbf{r}^{-1}$. The strainmeter signals of September 24, 1976, can be matched with a relaxation time of $1250 \mathrm{~s}$ and a propagation velocity of $2 \mathrm{~km} \mathrm{hr}^{-1}$. Intermediate values would be required to model the fourth event.

Our dislocation model is represented by an advancing front of dislocations of infinitesimal strength, with density exponentially distributed in space. Thus when the relaxation time is halved and the propagation velocity doubled, the spatial distribution of dislocation density in the slip front remains the same. Hence the wave forms are contracted by a factor of 2 but are not altered in shape. The initial extensional character of the wave forms from strainmeter I was essential for deducing these dislocation parameters. The simpler wave forms from strainmeters 2,3 , and 4 could be fitted by allowing the slip on the slip zone to grow in several different ways.

It is, of course, unrealistic to assume that the slip zone is a perfect rectangle on the fault with sides parallel and perpendicular to the ground surface. One would also expect the amount of slip to vary over the slip zone. In particular, it must decrease smoothly to zero at the boundaries. Propagation velocity and relaxation time may vary too. However, the upper 
boundary of the slip zone in our model cannot be moved more than about $10 \mathrm{~m}$ before a serious mismatch of the total offsets on strainmeters 1 and 2 occurs. The southeast boundary is also sensitive, although it is less likely to be vertical than the upper boundary is to be horizontal (see discussion below). Our model can only be taken as an approximation. But given our assumptions that the strainmeter events are due to one rectangular slip zone on the vertical fault plane, slip is right lateral strike slip, the ultimate amount of slip, propagation velocity and relaxation time are uniform over the slip zone, and the region may be treated as a homogeneous half space, our solution must be a good approximation to the real events.

\section{Discussion}

Initially, the most surprising feature of the dislocation model was that the dislocation did not reach the surface. In general, one would not expect the thin surface layer to have sufficient frictional strength on the fault plane to resist fracturing with the material below. This apparent increase in strength near the surface is postulated to be due to the depth of the water table. The thin surface layer does eventually fail; hence the events recorded by the Carr Ranch creepmeter. The similarity in shape of the wave forms recorded by strainmeter 1 during events, although they had different time spans, suggests that the propagation velocity of the dislocation front depends directly on the displacement rate at any point inside the slip zone. This is equivalent to saying that the spatial distribution of dislocation density remains the same when the relaxation time varies, which requires that the propagation velocity be inversely proportional to relaxation time.

The repetitive nature of this creep event may be due to an asperity on the fault or to an area of higher friction on a planar fault surface. Continuous steady slip on the fault plane around it repeatedly loads this region to failure. The 1966 ground breakage was not significantly more curved here than at many other points on the fault [Brown and Vedder, 1967], and the sediments in the valley are comprised of unremarkable deposits of clay, sand, and gravel. Either explanation is possible, and the absence of abnormal features suggests that similar creep behavior may be common along the fault.

Creep events at creepmeter installations often recur fairly regularly [Yamashita and Burford, 1973; Nason et al., 1974], so although this is the first observation of a repeated creep event well defined by strainmeters, it is unlikely to be unique. A similar phenomenon has been reported by Bufe et al. [1977]. They noticed the regularity of stick slip events (earthquakes with magnitudes in the range 3-4) along a 9-km section of the Calaveras fault.

The creep events observed by the Carr Ranch creepmeter are of small extent, but they are a result of slip over a more significant area of the fault below. As was discussed by McHugh and Johnston [1976] and Johnston et al. [1977], creep events on other creepmeters, which may also be of small dimensions, may be caused by earlier episodic slip at depth. In the observations of Mortensen et al. [1977], large creep events did break the surface. A problem arises if buried creep events occur with propagation velocities much less than $1 \mathrm{~km} \mathrm{~d}^{-1}$. Then the signals are far harder to detect over background noise, and dense networks of instruments will be required.

\section{Conclusions}

Four similar sets of signals have been obtained from an array of four strainmeters between 0.2 and $2.2 \mathrm{~km}$ from the San Andreas fault, $10 \mathrm{~km}$ southeast of Parkfield. The signals were separated by intervals of 4-5 months. A week after three of these four events, creep episodes began on the nearby Carr Ranch creepmeter amounting to about $3 \mathrm{~mm}$ of slip in each case. This creepmeter has recorded regular creep events on the fault since 1967. The strainmeter signals were fitted well by a simple dislocation model on the fault, assuming the ground to be homogeneous. The cause of the creep events could be an asperity or area of higher friction on the fault plane, which is repeatedly loaded to failure by continuous slip on the fault around it. Creep events recorded on the Carr Ranch creepmeter are themselves of small extent, but they are directly caused by the episodic nature of slip on the fault below. It is likely that this phenomenon occurs at many other locations on the San Andreas fault.

Acknowledgments. This project was started while N.R.G. held a research fellowship at the California Institute of Technology. He has since been supported by the Natural Environment Research Council. Funding was provided by the U.S. Geological Survey under contract 14-08-0001-15860. We thank the Hearst Corporation and Lorens Foard for permission to operate on the Jack Ranch; Don Anderson for initiating the project; Clarence Allen, Bob Burford, and Geoffrey King for discussions; and Tom Heaton, Nat Motta, Jose Rial, and Elmer Steffensen for practical help. Charles Frank and Stuart McHugh made useful criticisms of the manuscript. Contribution 2976 of the Division of Geological and Planetary Sciences, California Institute of Technology.

\section{REFERENCES}

Brown, R. D., and J. G. Vedder, Surface tectonic fractures along the San Andreas Fault: The Parkfield-Cholame, California earthquakes of June-August 1966, U.S. Geol. Surv. Prof. Pap., 579, 2-22, 1967.

Bufe, C. G., P. W. Harsh, and R. O. Burford, Steady-state seismic slip-A precise recurrence model, Geophys. Res. Lett., 4, 91-94, 1977.

Byerlee, J. D., and W. F. Brace, Stick slip, stable sliding, and earthquakes, J. Geophys. Res., 73, 6031-6039, 1968.

Frank, F. C., Dislocation models for fault creep processes, Phil. Trans. Roy. Soc. London, Ser. A, 274, 351-354, 1973.

Johnston, M. J. S., A. C. Jones, and W. Daul, Continuous strain measurements during and preceding episodic creep on the San Andreas fault, J. Geophys. Res., 82, 5683-5691, 1977.

King, G. C. P., and R. G. Bilham, A geophysical wire strainmeter, Bull. Seismol. Soc. Amer., 66, 2039-2048, 1976.

McHugh, S., and M. J. S. Johnston, Short-period nonseismic tilt perturbations and their relation to episodic creep on the San Andreas fault in central California, J. Geophys. Res., 81, 6341-6346, 1976.

Mortensen, C. E., R. C. Lee, and R. O. Burford, Observations of creep-related tilt, strain and water-level changes on the central San Andreas fault, Bull. Seismol. Soc. A mer., 67, 641-649, 1977.

Nason, R. D., F. R. Philippsborn, and P. A. Yamashita, Catalog of creepmeter measurements in central California from 1968 to 1972, Open-File Rep. 74-31. U.S. Geol. Surv., Menlo Park, Calif., 1974.

Press, F., Displacements, strains, and tilts at teleseismic distances, $J$. Geophys. Res., 70, 2395-2412, 1965.

Savage, J. C., and R. O. Burford, Geodetic determination of relative plate motion in central California, J. Geophys. Res., 78, 832-845, 1973.

Scholz, C. H., M. Wyss, and S. W. Smith, Seismic and aseismic slip on the San Andreas fault, J. Geophys. Res., 74, 2049-2069, 1969.

Smith, S. W., and M. Wyss, Displacement on the San Andreas fault initiated by the 1966 Parkfield earthquake, Bull. Seismol. Soc. Amer., 58, 1955-1973, 1968.

Yamashita, P. A., and R. O. Burford, Catalog of preliminary results from an 18-station creepmeter network along the San Andreas fault system in central California for the time interval June 1969 to June 1973, open-file report, U.S. Geol. Surv., Menlo Park, Calif., 1973.
(Received November 2, 1977; revised June 7, 1978; accepted June 8, 1978.) 